\title{
«О СЛОВО РІДНЕ, ХТО БЕЗ ТЕБЕ Я?» (ПРО СТИЛЬ ДОБИ ТА ІНДИВІДУАЛЬНИЙ СТИЛЬ ДМИТРА ПАВЛИЧКА)
}

Малюга Н. М. «О слово рідне, хто без тебе я?» (Про стиль доби та індивідуальний стиль Дмитра Павличка).

У статті йдеться про індивідуальну неповторність письменника у виборі вербальних засобів для відтворення мовної картини світу, про особливості реалізації можливостей художнього стилю відповідно до естетичного задуму автора.

Ключові слова: авторська мовна особистість, ідіостиль, художній текст.

Малюга Н. Н. «О слово рідне, хто без тебе я?» (О стиле эпохи и индивидуальном стиле Дмитрия Павличко)

В статье говорится об индивидуальной неповторимости писателя в выборе вербальных средств для репрезентации языковой картины мира, об особенностях реализации возможностей художественного стиля в соответствии с эстетическим засмыслом автора.

Ключевые слова: авторская языковая личность, идиостиль, художественный текст. 
Malyuha N. М. «О слово рідне, хто без тебе я?» (About the epoch's style and Dmytro Pavlychko's individual style)

The article deals with individual uniqueness of writer in the selection of the verbal means of the world scene's recreation; with the peculiarities of realization of the belletristic style's opportunities according to the esthetic author's intrntion.

Key words: author's, linguistic personality, idiostyle, belletristic text.

Нині проблема вивчення стилю літературного твору 3 урахуванням авторської мовної особистості посідає центральне місце в лінгвостилістичних дослідженнях. Основним об'єктом вивчення ідіостилю письменника $\epsilon$ сукупність мовно-виражальних засобів, які вирізняють його як індивідуальну особистість 3-поміж інших письменників.

Проблемі дослідження ідіостилю майстрів красного письменства через мову їхніх творів в українському мовознавстві присвячені праці В. Дроздовського, О. Кухар-Онишка, С. Єрмоленко, Н. Сологуб, Л. Ставицької, А. Мойсієнка, Н. Дужик, С. Бибик та ін. Мову художніх творів вивчають у різних аспектах: мовна майстерність (М. Бойко, І. Бородій, Г. В'язовський, I. Журба, Ю. Касім, О. Ковальчук, Т. Махед, О. Чехівський та ін.), багатство словника (Л. Авксентьєв, Е. Попович, Л. Яковенко та ін.), стилістичний синтаксис (Н. Грипас, В. Карпалюк, Л. Козловська, С. Марич, Н. Москаленко та ін.).

Сучасний лінгвостилістичний підхід до аналізу мови художнього твору вимагає всебічного врахування особливостей тексту через цілісний розгляд усіх його компонентів, особливо тих, що характеризують індивідуальний стиль автора, вирізняють мову окремого письменника 3поміж інших.

Із загальнонародної мови письменники відбирають і комбінують одиниці, спираючись на своє світобачення, об'єднують їх у своєрідну історично та естетично виправдану систему.

Поетична функція мови найбільш яскраво реалізується в ліричному тексті. Так, за влучним висловом Г. Синельникової, Т. Терновської, «ліричний вірш - це стометрівка на відміну від марафонського бігу епопеї», звідси «згущення значення через несподівані зближення слів, семантично вагомі повтори, роль внутрішньотекстових зв'язків на різних рівнях мовної структури» $[6$, c. 53]. 
Багатогранна змістом, вишукана формою, динамічна, енергійна, новаторська поезія Д. Павличка ось уже понад півстоліття впливає на українське суспільство. Породжена потужним інтелектом думка-ідея приваблює читача своїм словесним оформленням, місткістю і щільністю наповнення.

Мова поезій Д. Павличка багата й різноманітна, як і його життя, відображене у творчості. Багатьом талантам доводилося «і рости, і діяти» немовби в декількох вимірах, намагатися сказати слово правди в межах дозволеного; не випадково, що й «творчість Дмитра Павличка то немов автобіографія, викладена мовою поезіі, своєрідний поетичний автопортрет» [3, с. 34]. Поет самокритично оцінює свій доробок, що, цілком природно, викликає болісні рефлексії. Як активний громадський діяч, він пропускає крізь власний художній світ політичні зрушення в країні, дає їм оцінку (наприклад, вірш «Суд», надрукований у «Літературній Україні» від 06 жовтня 2011 року).

Метою нашої статті $\epsilon$ виявлення, систематизація та аналіз особливостей індивідуального стилю Д. Павличка.

Стиль письменника залежить передусім від ідіолекту (з грецької в перекладі означає свій та розмова, говір, наріччя), тобто від сукупності індивідуальних рис мови певної людини, зумовлених національністю, місцем проживання, віком, фахом, соціальним станом тощо. Авторська своєрідність у використанні мовних засобів витворює індивідуальний стиль (ідіостиль) письменника.

Досліджуючи стиль певного письменника, виділяють стильову домінанту. Маючи стильове «обличчя», письменник 3 кожним твором видозмінює його, оскільки змінюється тематика i порушувана проблематика (іноді - ідеологія), які теж є стилетвірними факторами.

Дослідження мовного аспекту ідіостилю дає можливість побачити індивідуальну неповторність письменника в представленій ним вербально-естетичній картині світу, оцінити його внесок у систему вже функціонуючих словесних художніх засобів національної мови, визначити загальні закономірності й провідні тенденції розвитку літературної мови.

Системність індивідуального стилю грунтується на формуванні мовної картини світу, яка поєднує загальне й індивідуальне, загальне й одиничне. 
Естетична функція художнього слова письменника, категорія індивідуального, уважає Л. Ставицька [7], створюється насамперед функцією повторюваності й закономірності, що формує естетичне організуюче ядро кожного ідіостилю. Ця функція пов'язана із значущістю художньої ідеї в авторській моделі картини світу. Внутрішня «ідіолектна норма» художнього мовлення формує категорію індивідуального в стилі письменника.

У процесі породження художнього тексту (дійсність письменник - образ - текст - читач) поверхнева структура його співвідноситься з глибинною структурою. Поверхневий рівень тексту, тобто його мовне оформлення, підпорядковується цілісній єдності тексту, але мовна форма також є актуалізатором глибинної структури.

Поглиблення функційно-стилістичного підходу до дослідження ідіостилю письменника спричинило активне вивчення семантичних можливостей слова в контексті, його реалізацію в комунікативно зумовленій позиції на тлі загальномовних процесів.

В українській лінгвостилістиці панує настанова на вироблення системних засад комплексного функційно-стилістичного аналізу мови художнього твору з увагою до онтологічної сутності гуманітарного знання, що сприяє найбільш повному та об'єктивному аналізу внутрішніх інтенцій художнього твору, виявленню естетичної вартості художнього слова, природи та сутності індивідуальних мовних картин світу. Осмислення авторської індивідуальності відбувається передусім на рівні інтерпретації мови художніх творів та встановлення принципів їхньої побудови. Ми поділяємо думку Г. Вокальчук про те, що «мовотворча діяльність як одна 3 форм духовного освоєння дійсності, як вид особливої комунікативної діяльності особистості спрямована на об'єктивне або суб'єктивне відбиття дійсності в мовних знаках, які вербалізують певне поняття чи асоціативно-художні, часом ірреальні, уявлення про світ, створюючи таким чином мовну картину світу» $[1$, с. 6].

Стиль доби завжди позначається на мовотворчості письменників. Досліджуючи мовотворчість поетів-вісімдесятників, I. Олійник доходить висновку: «Аналітичність і неординарність їхнього мислення виявляє себе у своєрідності текстових структур» [4, с. 4].

Оскільки слово $є$ носієм інтелектуального потенціалу, то вивчення специфіки його репрезентацій дає можливість з'ясувати 
особливості вербалізації індивідуально-авторського мислення, персоналізованої психологічної реакції на навколишній світ, художньо-еститичного моделювання в контексті інтелектуального розвитку вербалізованої національної свідомості.

Сучасний стан розвитку української ідіостилістики формує пріоритетність функційного напрямку дослідження мовотворчості: одиниці мови розглядаються як вербалізація індивідуально-авторського мислення, персоналізованої психологічної реакції на навколишній світ, художньо-естетичного моделювання свідомості. Саме цим визначається специфіка аналізу мовних одиниць у поетичних текстах, спрямована на визначення стилістичних функцій образно-виражальних засобів мовної структури. На думку Л. Домилівської, яка нам імпонує, лінгвістичне дослідження текстів художньої літератури акцентує увагу на науковій інтерпретації авторської мовної картини світу, особливостях функціонування мовних одиниць у процесі творення художньої образності як репрезентативного рівня ідіостилістики тексту, виявленні механізму трансформації мовних явищ у системі авторського художньо-мовного бачення світу [2, с. 55].

Індивідуально-авторский стиль Д. Павличка становить систему мовних засобів, яка сформувалася в результаті прискіпливого відбору i використання явищ мови не тільки для певного смислового навантаження, а й для естетичного впливу на читача. Комплекс думок і почуттів автора, що загалом становлять ідею твору, може виражатися засобами усіх мовних рівнів. Суб'єктивні наміри автора, його внутрішній світ та психологічні особливості суттєво впливають на осмислення, систематизацію й естетично-творчий підхід до добору мовних елементів вираження змісту.

Одним із найбільш цікавих і продуктивних при лінгвістичному аналізі тексту $є$ лексико-семантичний рівень, оскільки саме він повною мірою відбиває індивідуальні особливості стилю, своєрідність художнього методу письменника. Роль слова в художньому творі в процесі створення системи художніх образів неоднопланова. 3 одного боку, слово входить у національно-мовну систему, маючи постійне значення, а з іншого - у художньому тексті воно звернуте до світу дійсності, створеного автором. Тому в лінгвістиці тексту панує думка, згідно 3 якою 3'ясування нових смислових нашарувань, що перетворюють i збагачують семантичну будову загально-народних 
слів, виразів, конструкцій, композиційних систем мовлення, і становлять завдання науки про мову художньої літератури.

Послуговуючись загальновживаною лексикою, письменник не лише створює описи природи i зовнішності персонажів, а й психологізує їх. Художня активність нейтральних слів визначається в тексті твору. Майстерне поєднання нейтральних лексем може створювати яскравий художній образ, де лексема набуває реляційної значущості - синтагматичної цінності:

Теля покірне дві корови ссе,

Та иее в життя науці ще не все:

Вгодованих бичків беруть на бойню,

Худіших доля на лужках пасе (5, с. 121);

Наосліп ходить в яблуиі хробак.

Та не шукає виходу до світла (5, с. 100);

Тьма смерті очищає джерело

Людського зору, як пісок підземний-

Ті води, щзо прозріють у криниці (5, с. 41);

В иім житті ми всі банкрути,

Все зароблене - зола... (5, с. 180)

Поет оперує, крім теперішнього, минулим і майбутнім, але моделює ці форми часу так, що вони повертаються до читача у вигляді найболючіших питань сучасності.

На тлі загальновживаної лексики інша лексика доцільна для створення певного стилістичного забарвлення, наприклад просторіччя: Плюшева кохтина (5, с. 67); розмовні одиниці: Камінні більма, як у статуй, I сірість кам'яних одінь (5, с. 43); діалектизми: ...Безвстидно поскидали сорочки (5, с. 152); ...Живе камінний чоловік 3 обличчям кам'яним, похмурим, 3 вічми без вій $і$ без повік (5, с. 43).

Виражально-зображальне призначення експресивної лексики чи не найповніше втілюється в художніх текстах, безпосередній взаємодії 3 лексичними одиницями іншого стилістичного призначення:

«Боги забули нам послати зброю!»-

Кричали ми і жерлись між собою... (5, с. 150);

Небесний дар, призначений для бидла,

Несли ми на собі, як страховидла... (5, с. 150);

Таж я ту білку проклятущу

Лишень погладити хотів! (5, с. 163) 
Поезія Д. Павличка відтворює реальність сьогодення через призму тих політичних, економічних, культурних подій, які впливають як на свідомість, так i на почуття українців. «Антипоетичний словник» $€$ вираженням авторського ставлення, оцінної характеристики, засобом експресії художнього мовлення.

Мовленнєва ситуація та мовне оточення з'ясовують експресивні смисли лексичних одиниць, забезпечують умови функціонування їх актуальних значень. Виділяємо такі найголовніші функції контексту стосовно значення слова: відбір та актуалізація потрібного значення; трансформація смислу в межах семеми, його уточнення, конкретизація тощо; нейтралізація значень полісемічних слів; моделювання оказіональних значень; десемантизація значення.

Для реалізації експресивних значень однаково важливими, значущими є контексти обох типів - мовні (мовленнєві) та позамовні. Перші забезпечують сприятливе лексичне «середовище» для експлікації експресивного значення на лексико-семантичному рівні, а другі (ситуативні) виявляють чинники, що впливають на формування чи модифікацію образних та емотивно-аксіологічних смислів, установлюють тісні зв'язки між денотативною та сигніфікативною сутностями, мотивують середовище, умови, де відбувається комунікація. Вони враховують соціальний стан, вік, освіту, рівень культурного розвитку учасників мовленнєвих ситуацій; систему національних цінностей (релігійних, моральних, етичних тощо); етнічні традиції та стереотипи; особливості референтної сфери; позиції, інтенції та настанови автора та ін. Отже, у межах контексту значеннєвий план експресива перебуває під впливом двох світів: вербального (світу слів та їх значень) й об'єктивної дійсності, репрезентованої згаданими вище чинниками.

Письменник зосереджує увагу слухачів на емотивноаксіологічних значеннєвих планах лексичних одиниць, просодичних засобах, що беруть участь у моделюванні емотивно-оцінних (експресивних) значень:

Я бачив сонце, ніби ніж у крові,

Там, де в лісах кінчається земля,

І думав: щุо́, ну щио́ скажу корові,

Коли вона спитає, де теля (5, с. 49). 
Дбаючи про втілення своїх задумів, забезпечення оригінальності у висвітленні актуальних проблем життя народу, Д. Павличко активно залучає значний арсенал експресивних засобів, якими позначені всі мовні рівні, а особливо лексико-семантичний, що бере активну участь у відображенні фрагментів національної картини світу через призму власного «я». Саме він і є найвагомішим засобом суб'єктивізації художніх текстів та оригінальним виявом ідіостилю письменника.

Поява оказіональних одиниць нероздільно пов'язана 3 порушенням мовної норми. Відхід від мовної норми обов' язково має бути естетично виправданим. Коли людина має високе чуття мови, то вона вловлює всю чарівність відступів від неї.

Письменники намагаються змінити слово для того, щоб воно поновому вигранювало. Поява таких видозмін саме в поетичному творі пояснюється:

- дотриманням вимог силаботонічного віршування, зокрема збереження ритміки строфи:

I в темностях шаліють обороги,

Де пахне сіно груддю молодиць.

I виростають у святоші роги,

А ратички - в невинних янголиць (5, с. 69) (молодиць - янголиць); забарвлення:

- прагненням надати номінації відповідного стилістичного

Високе небо творчості,

Ти повне ластівочості... (5, с. 43);

I на твосму непороччі

Лечуя в безконечний гріх (5, с. 157);

3 рабів народжувались рабенята... (5, с. 151);

Не схожий він на Командора,

Що встав творити чесну месть (5, с. 43).

Як бачимо, Д. Павличко активно використовує неологізми, зокрема авторські, адже спосіб мислення творчої людини просто неможливо втиснути в якісь рамки.

Ознакою майстерності автора є вдалі метафори. Метафори Д. Павличка образні, яскраві, вони легко створюють зорове уявлення i бажаний поетові настрій. Наділені посиленою експресивністю, суб'єктивністю у сприйманні світу, вони виконують важливу естетичну функцію. 
Кожна метафора є, по суті, скороченим порівнянням. Проте якщо в порівнянні схожість вказана прямо, то в метафорі опосередковано. У цій лаконічній образній формулі неприпустимі зайві деталі, як-от: обставини місця і часу. Метафора Д. Павличка є не лише ресурсом образного (поетичного) мовлення, але й джерелом нових значень слів, які здатні виконувати описову та номінативну функції, закріплюючись за індивідом як його назва. Наприклад:

Смаглява ніч в колисиі гір

Гойдала місяия малого.

Чоло біленьке як папір

І голубі очата в нього (5, с. 49);

Я пам'ятаю дом, який ходив за мною,

Немов теля. Лизав, пригладжував слюною

Мій непокірний чуб. І запах молока

Лишавсь на голові... І жаль мені донині,

Що гострим батіжком я бив його по спині

I відганяв той дощ од себе, як бичка (5, с. 74);

3 неба голубої миски

Ллється спека (5, с. 50);

Черешня, як та мати, край дороги,

У жиляках селянські чорні ноги.

Сорочка иявіту білого на ній -

Мережка у блакиті весняній $(5$, с. 55).

Сконцентровуючи та узгоджуючи у своєму потужному семантичному полі найвіддаленіші чи найнесумісніші асоціації, метафора постає суцільним нечленованим тропом, який може розгортатися у внутрішній сюжет, не прийнятний 3 погляду раціоналістичних концепцій. Метафора подібна до загадки, але 3 тією відмінністю, що не підлягає декодуванню, вимагаючи визнання за собою нової реальності, побудованої за естетичними принципами.

Поет, удосконалюючи художню вартість своїх творів, удається до парономазії. Д. Павличко добирає не перше-ліпше близькозвучне слово, а саме те, яке задовольняє більш високим вимогам, не тільки формально-естетичним, але й семантично-образним:

Я долаю струс і стрес,

Я з тобою граю й граюсь

За сиенарієм небес $(5$, с. 175$)$; 
Він біг, немов стелився в ковилі;

Серия ж гатили, наче ковалі $(5$, с. 154).

Дмитро Павличко - естет, він залюбки вдається до мовної гри, розрахованої на поціновувачів слова, його поезія наскрізь пронизана відчуттям драматичних суперечностей у світі, людській душі. Поет шукає гармонічні співзвучності не тільки між явищами світу, а й поміж звичайними словами мови. Цей пошук породжується ще й глибоким внутрішнім поетичним чуттям i прискіпливим «філологічним відбором».

М. Лубківський справедливо пише: «Не знати в сучасній нашій літературі іншого автора, який так досконало володів би даром телескопічного і мікроскопічного проникнення за межі тривіального побуту, так мудро і міцно зв'язував би найвіддаленіші асоціації, так лагідно і співчутливо сприймав усе, що діється навколо нього, але не відмовлявся й від іронії та сарказму...» [3, с. 23]. Наприклад:

Тим часом намі дорогі подруги

Не помирали в самотині з туги,

А брали наших слуг собі в мужі,

Дітей родили, мов пекли коржі! (5, с. 151).

Д. Павличко майстер шифрувати підтекст, майстер алюзій:

Караюсь, мучуся і каюсь

В провинах тих, яких нема! (5, с. 196);

Ніхто не хоче викидати гній

Зі стаєнь там, де панував Авгій... (5, с. 204).

Така поезія розрахована на ерудованого читача, адже для неї характерне використання тонких натяків на твори інших письменників, історичні та міфологічні сюжети. Для лінгвістичного аналізу багатьох віршів важливо враховувати міжтекстовість, закладену в смислову програму тексту.

Літературно-художній твір як діалектична єдність раціонального, естетичного й емоціонального, як система словесних художніх образів - це не тільки образне відтворення дійсності й естетичного освоєння світу. У кожному художньому творі закладені можливості відповідного впливу на почуття, свідомість і волю читача. Поет не дозволяє собі бути вульгарним, коли йдеться про інтимну сферу, тут він дуже обережно добирає кожне слово:

Я поруч був. Я відгортав

Краї сорочки і спідниці. 
Я серед запахущих трав

На грудях бачив дві сунииі,

Дві ягоди із молоком,

Снагою внутрішньою ситі... (5, с. 182);

Хто там зчинив переполох,

На діло дивлячись пошлюбне...? (5, с. 179);

Боялися, щзо наша кінська хіть

Оберне нас на коней мимохіть (5, с. 152).

Д. Павличко має тонке відчуття художнього слова, вродження почуття міри, йому властива висока елегантність поетичної манери, що визначає ретельний відбір тих чи тих мовних засобів. Лексема як самодостатня одиниця в художньому тексті віддзеркалює особливості індивідуальної мовотворчості митця слова.

Проблема поетичного синтаксису як надзвичайно важливого компонента поетичної мови загалом та конкретного індивідуального авторського стилю (ідіостилю) зокрема не висвітлена належним чином у працях українських мовознавців. Попри те, що в поетичному синтаксисі «конденсується зміст думки, переданої в певній ритміко-інтонаційній динаміці, в індивідуальній неповторній тональності ліричного монологу» [6, с.57], він залишається на периферії досліджень, адже особливості синтаксису не так рельєфно проступають на площині художнього тексту, як явища лексичні.

У композиції речення найвиразніше відображається спосіб вербального формування думки в процесі творення тексту, а отже, реалізується властива конкретному авторові специфіка застосування синтаксичних засобів художньої комунікації.

Загалом у текстах Д. Павличка (прихильника класичного римування) переважає плавний ритміко-інтонаційний лад вірша, притаманний українським народним пісням, тому цілком природно, що пісні «Два кольори», «Долиною туман тече», «Явір і яворина», «Лелеченьки», «Впали роси на покоси...» та ін. (муз. Олександра Білаша) завоювали любов і популярність.

Новатором форми назвати Д. Павличка важко, оскільки його поетична мова відзначається превалюванням синтаксично повних речень, які не вступають у конфлікт із ритміко-інтонаційною структурою вірша, здебільшого завершення речення збігається із завершенням віршового рядка або цілої строфи. Досить часто, що 
загалом є типовим для віршованої мови, автор використовує інверсивний порядок оформлення речення:

Hi, не буде

Душі людської зігрівати

Дзвінкою мовою чужсо

Перевертень... (5, с. 41);

За кожну кулю по копійці

Йому сплатила вже казна (5, с. 44) (інверсія: присудок-підмет, додаток перед присудком, означення після додатка).

Інверсія $є$ вдалим прийомом виділення змістової значущості, надання фразі особливого стилістичного забарвлення.

У творах Д. Павличка наявна велика кількість звертань, їх можна розподілити на такі групи:

1) риторичні звертання:

Tарасе! Правдо вогнелика!

Мій боже, вірую - ти є! (5, с. 47);

2) звертання, якими гукають, просять когось, закликають:

Стала біля нього Смерть:

- Добрий день, дідуго! (5, с. 139);

3) звертання 3 виразною спонукальною функцією попереджувальною, заборонною, наказовою:

Цар подумав: "Щось тут є...»

- Говори, хлоп'я моє (5, с. 137);

Дивіться, Ярославно, на щчитах

Його несуть хоробрі побратими,

Та ви лише скажіть йому: «Максиме!...» (5, с. 91);

4) звертання, що виражають різноманітні реакції мовців, їхні внутрішні переживання; вони передаються інтонацією, підказаною текстом:

Дівчино, мій пишний короваю,

Я тебе люблю, та не кохаю,

Бо якби кохав, мій хлібе сущчий,

Відкроїв би краєщь запахущий,

I спожив би, наче тіло Бога...

Але ж ні, моя ти струнконога,

Не торкнусь тебе, росино рання,

Хоч би вмерти мав з голодування (5, с. 176). 
Письменник тяжіє до використання вставлених конструкцій. В окремих випадках припадає по дві і більше вставлені конструкції на одне основне речення:

Сліди від округлого хліба

(такий моя мати випікала),

пляму від розлитого молока

(моя неуважність!),

а далі, немов на екрані,

побігли на ній кадри з мого дитинства (5, с. 265).

У Д. Павличка є вірш «На цій землі жили ми споконвік...», у якому обсяг вставлених конструкцій перевищує обсяг основного тексту:

На иій землі жили ми споконвік,

Лише обличчя змінювали трохи.

(Так змінює своє русло потік,

Але вода клекоче крізь епохи

Одна і та ж!) Одна і таж душа

Вела мене то під варязькі шатра

(Там танеиь твій у люстрі палаша

Виблискував і пригасав, як ватра),

То під мечетей вилинялий крик

(Там ти - в петлі, а може, $i$ в намисті, -

Хан ластився до тебе, мов арик,

Свої дари приносячи нечисті),

То під готичних знаків нагаї

(Там вигоріли кісники твої,

В сивинах, як огні знамен когорта) (5, с. 167).

Вставлені конструкції різні за будовою і характером зв'язку 3 основним реченням. Серед них прості непоширені двоскладні одиниці: Закричи з жалю до мене Люто й зло, Щоб моє життя натхненне Ще жило, Щоб виймав я - ти ж горіла! - Біль солодкий з твого тіла, Як бджоли жало (5, с. 170); прості поширені повні двоскладні структури: I досі - тільки сном візьмуться очі - Я чую журні мамині слова, Лечу стежками поміж ниви отчі, де кров'ю сония збризкана трава (5, с. 49); прості поширені неповні двоскладні речення: Пожсиачі м'ясива та кав'яру. Мішки, набиті кільиями ковбас, Чи мав би я - а за яку ж то кару? - До боротьби запалювати вас! (5, с. 193); односкладні речення: 
Цей світ, немов митець (Далі, Марчук, Шагал), Нормальний чоловік, щуо не впадає в шал, Але він творить нас шаленими й спокійно Спостерігає наш кривавий карнавал (5, с. 133); Я, слава Богу, вивчився потрошку, Хоч діло ие (не смійтеся!) складне (5, с. 94); складні речення зі сполучниковим і безсполучниковим зв'язком (див. приклади з вірша «На цій землі жили ми споконвік...»); надфразні єдності: Тоді мерщзій - Із круглих спин здирати гній Та на свинячому хребті Шукати літери святі... (Колись начальство наказало, Щоб окремішно від усіх Для нього підсвинка на сало Годовано було. На сміх Позначили свинарки милі Начальственним ім'ям свиню). Отож погладь ї̈ по рилі! - Яви пошану їй свою $(5$, с. 45$)$.

Розглянуті вставлені синтаксичні конструкції виконують у реченнях найрізноманітніші функції: допомагають створити цілісне уявлення про діючих осіб, повідомляють додаткові біографічні дані, називають умови, обставини й т. ін., коли відбувалися події тощо.

Для підсилення особливого емоційного стану, внесення у твір схвиљьованості, піднесеності, акцентуації на певних позиціях поет часто вдається до риторичних запитань. Оскільки таке питання не потребує відповіді, воно фіктивне, проте його сила базується саме на властивій питальним реченням інтонації очікування відповіді, інтонації, покликаній привернути увагу читача:

Де я живу, скажіть? Чому проти рожна

Щодня я мушу йти, кому найнявся в кмети,

Для кого я пишу цуі київські сонети,

Коли на довкруги - суцільна чужина? (5, с. 90).

У той час як розповідні й спонукальні речення можуть мати емоційне забарвлення (є окличними), а можуть бути й емоційно нейтральними (неокличними), питально-риторичні речення завжди супроводжуються емоційно-експресивним забарвленням. Крім того, питально-риторичні речення - конструкція гнучка, багата різними можливостями. Ними можна виражати почуття, роздуми. Насиченість віршів питально-риторичними конструкціями акцентує увагу на тому, про що йдеться в питанні.

У досліджених поезіях виявлено синтаксичні конструкції, які складаються із запитання і відповіді. Основне призначення їх зосередити увагу читача на окремих фактах. У художній мові Д. Павличка це засіб увиразнення, збільшення експресивності:

О рідне слово, хто без тебе я? 
Німий жебрак, стариюючий нетяга,

Мертвяк, оброслимй плиттям саркофага,

Прах, купа жалюгідного рам'я (5, с. 88).

Одним 3 організуючих засобів поетичного тексту є повтор. Повтор окреслює реалії дійсності та акцентує на них увагу, а дистантно розміщені повторювані одиниці формують композицію твору, дозволяють виявити ключові поняття. На використанні лексичних, синтаксичних повторюваних мовних засобів базуються наскрізні теми. Використання повтору створює атмосферу не просто інформування про події, а живої розповіді:

Сусіди, і щури, і миші, і газети,

I телевізора смертельного мана - все чужомовне, все (5, с. 90);

Та в стогонах я розпізнав слова

I зрозумів - вона жива, жива! (5, с.162);

Вона смісться гірко: "Чоловіки?

Були, були, звичайно, та не ті» (5, с. 177);

Поклич мене сама, поклич,

Поклич сама,

Тоді візьму я в руки бич

Теж мовчкома! (5, с. 171);

Трупи, трупи,

Студених тіл труйливі купи

I більи нічого! (5, с. 189).

Природно, що 3 повторюваністю мовної одиниці пов’язана смисловидільна функція, яка полягає в акцентуванні уваги не лише на елементах конструкції, а й на підтекстових смислах.

Крім моделей зі сталою структурою, у тексті функціонують трансформовані системи, ключові елементи яких, повторюючись у новому контексті, набувають додаткових відтінків. Повторюваними постійними величинами можуть виступати ключові слова, образи. Послідовно вживані мовні засоби здатні набувати нових асоціацій та вражень: То чим же ми гірмі за пана поляка? (5, с. 191); То чим же ми гірші за чеського брата, За брата словацького? (там само); То чим же ми гіриі за угра й румуна... (5, с. 192); То чим же ми гірші за наших сусідів...? (там само); А тим же ми гірші, щуо йшли в яничари, Пишалися рабством, розводили чвари, За ласки володаря крихту малу... (там само). 
3 кожним разом повторюване речення посилює експресивне навантаження:

Нi! Прийди, не дай померти

Від самотності! Прийди! (5, с. 180)

Основна функція повтору - художнє увиразнення мови, зміцнення іiі експресивно-зображальних властивостей. Повтор сприяє відображенню хвилюючих моментів у житті людини, стану збудження, підвищення емоційного реагування на щось. Отже, у смисловому плані повтор не механічний процес, а важливий момент організації тексту, не менш відповідальний, ніж вибір і вживання іншого, нового, слова. У канві художньої оповіді повтор виконує композиційну, смисловидільну функцію.

Однакове розміщення членів речення - показник структурного паралелізму. Симетричне розташування посилює ритмічність конструкції, підкреслює однотипність побудови компонентів, які при цьому зазнають актуалізаціі. Паралелізм підтримується також тотожністю форм вираження членів речення:

У небесах схоластики

Не видно мислі-ластівки,

Не видно думки-блискавки,

Що бігає навискоки (5, с. 42);

Ми прагнем слова - не зітхання,

Жаги життя - не житія! (5, с. 47).

Структурний паралелізм $є$ ознакою книжного мовлення. Наявність конструкцій, побудованих за цим принципом, у поетичному мовленні цілком закономірна.

Яскравим та індивідуально-авторським почерком вирізняється в канві текстів один з улюблених тропів Дмитра Павличка - порівняння. Порівняння містить у собі метафоричність співставлення поєднуваних понять, підкреслює і підсилює образ одного предмета чи явища за рахунок іншого, викликає певні естетично направлені асоціації та почуттєво-оцінні реакції.

До основних функцій, які виконує операція порівняння, належить встановлення тотожності (повної або часткової) та відмінності між порівнюваними об' єктами.

За типом компаративної модальності розрізняють логічні та образні порівняння, традиційно розмежовуючи їх на основі зіставнокількісних та чуттєво-образних показників. Мета зіставлення в 
логічному порівнянні - лаконічно пояснити сутність одного предмета шляхом його порівняння з іншим або показати, наскільки гарним / поганим $є$ предмет, який порівнюють, стосовно об'єкта, який більшість мовців оцінює як позитивний чи негативний. В образних порівняннях зіставляють одиниці однакових та різних класів. Як логічні, так і образні порівняння зорієнтовані на пізнання об' єктивної та уявної реальності, хоч указують на непряму характеристику предмета.

Серед об'єктів порівняння в поезії Д. Павличка найбільш частотними є одиниці таких класів: 1) явища природи; 2) рослини; 3) побутові речі; 4) людина: Золотою Йду травою, як водою, Коники 3-під ніг - як бризки. Блискотить, як мирисниця, Сонще у моєму глеці... (5, с. 50); Мосяжним топірием опришка На грущиі висить молодик (5, с. 52); Стоять з дощзами хмари на горі, Так ніби вийшли $з$ штольні шахтарі. Там блискавиця біла, як береза, Або як сміх у вугільній журі (5, с. 122); Твоя душа звіздаста і смаглява, Як ніч, щзо светра віхоли зняла. Твоє волосся пахне, як отава 3-під скатерті різдвяного стола (5, с. 158); Напав я на тебе раптом На стежиі посеред cmenу, Нахлинув, як дощ краплистий, Як проливень буревійний, Липневий джигун-музика, Просяяний блискавками, Співаючий дощ любові (5, с. 163); Я в пазуху зайду тайком, Неначе злодій до комори. Там пахнуть груди молоком, Мов травами гуиульські гори (5, с. 172).

Письменник уникає традиційних порівнянь, він майстер оригінальних конструкцій, що відображають його світосприйняття. Порівняння є одним із складників процесу відображення дійсності у свідомості людини і відтворення їі в мовній діяльності. Порівняльні звороти входять до системи понять, за допомогою якої носії мови сприймають, класифікують та інтерпретують світ.

Отже, авторська своєрідність у використанні мовних засобів витворює індивідуальний стиль (ідіостиль) письменника. Сукупність зображально-виражальних засобів письменника тоді дає ефект, коли закономірно поєднується в художньо мотивовану систему, зумовлену індивідуальністю митця.

Дослідження мовного аспекту ідіостилю дає можливість побачити індивідуальну неповторність письменника у представленій ним вербально-естетичній картині світу, оцінити його внесок у 
систему вже функціонуючих словесних художніх засобів національної мови, визначити загальні закономірності й провідні тенденції розвитку літературної мови.

Аналіз художніх творів Дмитра Павличка дає змогу говорити про створення індивідуально-авторського стилю шляхом прискіпливого відбору і використання явищ мови не тільки для певного смислового навантаження, а й для естетичного впливу на читача.

Для лінгвостилістики такі дослідження цікаві насамперед тим, що показують, як реалізуються можливості художнього стилю відповідно до естетичних задумів автора, як мовотворчість окремого письменника збільшує i збагачує виражальні засоби загальнонаціональної мови.

\section{Література}

1. Вокальчук Г. М. Словотворчість українських поетів XX ст. : [монографія] / Г. М. Вокальчук ; відп. ред. С. Я. Єрмоленко. - Острог : Національний університет «Острозька академія», 2008. - 200 с.

2. Домилівська Л. В. Теоретичне обгрунтування категорій ідіостилістики в сучасному мовознавстві / Л. В. Домилівська // Компаративні дослідження слов'янських мов і літератур : [зб. наук. пр.]. - Вип. 10. - К. : Знання, 2009. - С. 54-61.

3. Лубківський Р. Сповідь. Молитва. Присяга : [передм.] / Роман Лубківський // Павличко Д. В. Ялівець : Поезії / Павличко Дмитро Васильович ; упоряд. і передм. Р. М. Лубківського ; [Іл. В. В. Кузьменка]. - К. : Веселка, 2004. - С. 5-34.

4. Олійник І. Г. Мовотворчість поетів-вісімдесятників (текстові структури та поетичні номінації) : автореф. дис. на здобуття наук. ступеня канд. філол. наук : 10.02 .02 / І. Г. Олійник. - К. : АН України, Ін-т укр. мови, 1993. - 17 с.

5. Павличко Д. В. Ялівець : Поезії / Павличко Дмитро Васильович ; упоряд. i передм. Р. М. Лубківського ; [Іл. В. В. Кузьменка]. - К. : Веселка, 2004. - 399 с.

6. Синельникова Г. Особливості семантичної структури ліричного вірша й методи його аналізу / Г. Синельникова, Т. Терновська // Вісник Луганського університету. 2002. - №4. - C. 53-57.

7. Ставицька Л. О. Про характер взаємодії категорії індивідуально-поетичного стилю і літературної мови / Л. О. Ставицька // Мовознавство. - 1986. - №4. - С. 61-64.

Стаття надійшла до редакції 31.07 .2012 p. 